\title{
Children and Adults With Profound Intellectual Disabilities in Poland: Legal Issues and Educational Services
}

\author{
Diana Aksamit ${ }^{1}$ and John J. Wheeler ${ }^{2}$ \\ Institute of Special Education, The Maria Grzegorzewska University, Poland \\ ${ }^{2}$ Department of Ed Foundations and Special Education, Clemmer College of Education, \\ East Tennessee State University, United States
}

\begin{abstract}
HOW TO CITE:
Aksamit D., Wheeler, J.J. (2020).

Children and Adults

With Profound Intellectual

Disabilities in Poland:

Legal Issues and Educational

Services. International Journal

of Special Education, 35(2), 5-18

CORRESPONDING AUTHOR:

Diana Aksamit;

daksamit@aps.edu.pl

DOI:

https://doi.org/10.52291/

ijse.2020.35.9
\end{abstract}

\section{COPYRIGHT STATEMENT:}

Copyright: (C) 2020 Authors.

Open access publication under

the terms and conditions

of the Creative Commons

Attribution (CC BY)

license (http://creativecommons.

org/licenses/by/4.0/).

\section{ABSTRACT}

The aim of this paper is to present the reality of education and rehabilitation faced by people with profound intellectual disabilities in Poland; as seen from the perspective of the past, present, and future, with an attempt to identify the determinants of these situations. The paper addresses these matters in a threefold context which includes a description of the specific characteristics of the educational and rehabilitation situations of people with profound intellectual disabilities in Poland, an analysis of the characteristics of diagnosis as well as the structure of the education system, and alternatives for adults with profound disabilities.

Researchers conducted an extensive analysis of literature, legal acts and government reports presenting and evaluating the situation of people with profound intellectual disability from childhood to maturity in Poland. The results of this study make it possible to get to know and better understand the situation of the discussed group of people and their carers. Furthermore, the theoretical analyses carried out show that the structure of education offered to people with profound intellectual disabilities in Poland requires change that takes into account the autonomy of the individual and their rights in the context of national and international legal mandates.

Keywords: education; rehabilitation; profound intellectual disability; complexity of the support system 


\section{INTRODUCTION}

The development of each person takes place in the context of his relationship with the environment which refers to the theory developed by Urie Bronfenbrenner (1974) called "the ecology of human development”. According to the given concept, the social environment is understood as a system of interdependent ecosystems (microsystem, mesosystem, exosystem, macrosystem and chronosystem) (Bronfenbrenner, 1975, 1989; Bronfenbrenner \& Morris, 1998). Human development is influenced by a given environment, but people also influence each other. The social environment of each person is a system of interdependent subsystems and constitutes an individual developmental context. A disturbance in the functioning of one element affects the operation of the entire system. The basic elements of the development system of people with profound intellectual disabilities are: the closer and more distant families and the peer environment. In this article, we will focus more on the support environment, as well as the state policy in the field of creating conditions for supporting the development of people with profound intellectual disabilities in the past-present-future perspective.

This also finds a specific analogy in the concept of social and cultural diagnosis of reality by Clifford Geertz (2000). The analysed reality of people with profound intellectual disabilities can be related to the reality presented by the author of the aforementioned concept. Therefore, we assume that the reality of people with profound intellectual disabilities is a "world in pieces”, a ,jagged world” in which the structures of coherence, (or apparent coherence), are broken down into poorly connected smaller fragments. In the article we will try to present this ,jagged world" of people with profound intellectual disabilities from childhood to maturity, referring to the existing regulations, legal acts, and systems of practical solutions in Poland. We assume that the „fragmented” world of people with severe intellectual disabilities enforces a specific way of experiencing it, that is, piece by piece.

The Polish system of education has remained unique with regard to the place occupied by people, (children, young people, adults), with profound intellectual disabilities within that system. In the context of the past, it was expressed that people with profound intellectual disabilities were „invisible” in practical terms in the education system, only in legal terms as a mention in the regulations (Kopeć, 2013; Marcinkowska, 2013; Wrona, 2011). The exemption from compulsory schooling for individuals with profound intellectual disabilities was adopted and applied in Poland for many years until 1997, regardless of the supposed right to education for every Polish citizen (Orkisz et al., 2008; Piszczek, 1997). Such groups were denied the right to free and appropriate education in the past, and also at present. Individuals with profound disabilities are the only group of people in the Polish education system not referred to as "pupils" (Journal of Laws of 2013, item 529). This is particularly problematic because of the many legal acts regulating the system of educating students with disabilities. However, these legal acts do not take into account children with profound intellectual disabilities.

The legal system refers to them only as class participants (Journal of Laws of 2017, item 1591). Special education institutions represent the only practical alternative in the context of the education and rehabilitation of individuals with profound intellectual disabilities in Poland (Gawlik \& Gomola, 2018; Kopeć, 2007). The question as to whether or not broadly described systems of integrated and inclusive education as a measure of success for persons with disabilities, are also available to individuals with profound intellectual disabilities, which should be guaranteed, for example, by The Convention of the United Nations on the Rights of People with Disabilities of 2006, ratified by Poland (Journal of Laws of 2012, item 1169). Minimal and superficial interest on the part of the state on the issue of persons with profound intellectual disabilities in the context of education, (referring to changes in regulations and structure, funding for research carried out in higher education institutions in this area in comparison with funded research on, inter alia, autism, Asperger's syndrome, Down's Syndrome, other degrees of intellectual disability), (Aksamit, 2019).

Several aspects are mentioned which point to the current condition concerning the educational and rehabilitation reality for persons with profound intellectual disabilities in Poland. Pursuant to the laws of Poland, persons diagnosed with profound intellectual disabilities since birth, and/or when there is a risk of this level of disability at the time of pregnancy, are dealt with by the sector of the Ministry of Health on matters related to the typological diagnosis, treatment, psychological assistance, and early intervention assistance for the child and the family. The Ministry of Labour and Social Policy provides financial support in the form of benefits on behalf of these individuals and families, and the Ministry of National Education maintains oversight in the area of education which 
can include education and rehabilitation in: kindergarten, school, revalidation, and educational centres - implementation of revalidation and education classes. In the context of education and rehabilitation, a person with profound intellectual disabilities up to the age of 25 falls into the area of interest of the Ministry of National Education (Journal of Laws of 2013, item 529), and beyond that age, in the context of education and rehabilitation, of the Ministry of Labour and Social Policy (Journal of Laws of 1997, No. 123, item 776; Journal of Laws of 2020, item 426).

Although the reality in the domain of education and rehabilitation of persons with profound intellectual disabilities is conditioned by law, it is different from the education of children, young people, and adults (sometimes discriminatory in comparison with individuals with other types of disabilities) (Krause, 2010; Marcinkowska, 2017). These characteristics will be analysed further in this paper.

\section{A HISTORY OF INVISIBILITY IN SOCIAL AND SCIENTIFIC DISCOURSE}

The system of support for persons, (children, young people, and adults), with profound and complex disabilities in Poland has had an institutional character for many years. This means that there have been large care facilities i.e., institutions in which a number of people with disabilities stay, which, due to their medical approach to disability, do not place much emphasis on the quality of life of these individuals but rather on the biological aspect - medical treatment as the basic form of support. Historically, families who did not opt for this kind of solution have had to provide long-term care for a child or an adult on their own. Studies show that the majority of today's adults with profound intellectual disabilities have never participated in any form of organised care (Aksamit, 2019; Kopeć, 2013).

These are individuals whose development, for most of their lives, has not been sufficiently stimulated, and therefore any progress was doomed to decline (Doody, 2011; Fullerton et al., 1999; Prysak, 2015). Due to their persisting status of ,invisibility' they were also absent from Polish scientific studies (Marcinkowska, 2013). Among other things, the specific character of the scientific research, because of the difficulty in selecting a group due to co-occurring disabilities, as well as the lack of a theoretical and conceptual framework developed on Polish soil (Babbie, 2008; Flick, 2011) is lacking. Some of the major factors are social perception, knowledge, public awareness of the specificity of the disability and the people affected by it, are seen as ,eternal children”. Also rooted in Polish society, and persisting in both social and scientific discussion only, is a stereotype of the negative characteristics of functioning, needs and abilities of persons with profound intellectual disabilities (Jankiewicz et al., 2014; Piszczek, 2006). It should also be pointed out that there is a lack of social research on the level of awareness in Polish society about persons with profound intellectual disabilities. These factors have over the years resulted in the current educational and therapeutic options for addressing the educational and rehabilitative needs of persons with profound intellectual disabilities in Poland.

\section{DIAGNOSIS}

Prenatal diagnostic methods have been developing for many years in Poland (Frączek et al., 2013). The year 2020 will go down in the history books of Poland due to the Constitutional Court passing a law that prohibits the abortion of a child due to lethal developmental defects, which was historically a decision for parents to make. Since November 2020, debates and social protests have been taking place in Poland. Thousands of people have taken to the streets to demonstrate their disapproval that women are being deprived of their right to choose to terminate pregnancy if the fetus has lethal developmental defects. On the other hand, pro-life activists and the Catholic Church are against the protests and claim that human life is sacred, and no one has the authority to choose to terminate it by themselves. This is a topic for a separate scientific study, but it cannot be omitted when diagnosing a profound intellectual disability. Interestingly, in the social debate in Poland, many mothers are in favour of the right to terminate pregnancy if the child has lethal developmental defects. However, the research conducted in the group of mothers of adults with profound intellectual disabilities has revealed that the majority of them claim that, even if they had known that their child would have profound intellectual disabilities in the future, they would not have had an abortion (Aksamit, 2019). It should be noted that at that time there were no prenatal diagnostics in Poland that would be able to reveal such defects, but regardless of this, women had the right to choose termination if such information came from a doctor.

It is estimated that there are approximately 93 million children under the age of 14 with disabilities worldwide, and 13 million of these children have the most severe 
disabilities, including profound intellectual disabilities (Arvio \& Sillanpää, 2003). The accuracy of global statistics is difficult to ascertain because each country has its own definition of profound intellectual disability, as well as different ways of diagnosing and classifying them. In Poland, there are definitions included in the international ICD-10 classifications, according to which profound intellectual disability consists of the reduction of many cognitive processes and functions, compliance with one side at the level of intelligence, (measured intelligence according to various tests, in ICD-10) below 20 points), and the individual's ability to cope in social and cultural conditions (Cierpiałkowska, 2007, p.176).

In the event that a child would have a disability and this is discovered during pregnancy, the mother is provided with psychological assistance in the scope of early intervention which is within the oversight of the Ministry of Health. Developed organisational standards of perinatal care in Poland assume that the patient has access to psychological assistance in hospital both before and after giving birth. After delivery, the child is assessed by neonatologists and pediatricians; after leaving the hospital, the parent receives referrals from the pediatrician to other specialists (pediatric neurologist, psychiatrist depending on the need). If necessary, the parent receives referrals to the early intervention centre where he or she attends therapy with the child (Journal of Laws of 2017, item 1635). The Polish system of diagnosing people with disabilities in the context of disability assessment is extensive and has a complex structure. There is a system of medical certification for education purposes applicable to people with disabilities up to the age of 25 , and medical certification for pension and non-pension purposes granting the status of a disabled person to both children and adults.

In Poland, intellectual disability is diagnosed at four levels: mild, moderate, severe, and profound (ICD, 10). Such a diagnostic distinction is particularly important in the context of the education process. The diagnosis of the degree of intellectual disability is also important in assessing disability for non-pension purposes of children and adults, since only people with „moderate”, „severe” or "profound" intellectual disabilities can be officially recognised as a person with a disability. Disability certificates for non-pension purposes are issued by Disability Assessment Teams and these teams issue certificates to people over the age of 16 stating one of three degrees of disability: „mild”, „moderate” or „severe”.
The assessment of disability and the activity of disability assessment teams is regulated by the Act on Vocational and Social Rehabilitation and Employment of Persons with Disabilities (Journal of Laws of 2020, item 426). A separate system of certification determining entitlement to disability benefits for adults operates within the Social Insurance Institution (ZUS). The medical certification in the context of the rehabilitation of people with profound intellectual disabilities less than 25 years of age in Poland takes place in psychological and pedagogical counselling centres operating under the supervision of the Ministry of Education. Through this system of assessment, a person with profound intellectual disabilities receives a document: a certificate confirming the need for revalidation classes which is issued for up to five years (Journal of Laws of 2017, item 1743). This document allows the person to pursue pre-school and school education by attending revalidation classes. In Poland, there are no specialised psychological tests enabling the assessment of the intelligence quotient of people with the most severe forms of disability. Through testing it is often not possible to discover the full potential of a child's abilities, including his or her needs, due to the complexity of the disorders that accompany them. This psychological diagnosis uses the same testing methods as for any other child in Poland whose intelligence quotient is measured; the situation is similar in terms of functional assessment tools which are also missing in Poland.

Over the years, several tools have been adapted for this type of functional assessment of a child with profound intellectual disabilities, among those most commonly used in practice, the following should be listed: PAC Inventory by H.C. Gunzburg adopted in Poland by Tadeusz Witkowski (1988); Student Achievement Profile (Kielin, 2002); The Questionnaire for the Assessment of Communication Methods Used by People with Profound Intellectual Disabilities (KOSK) (Marcinkowska, 2012). The nature of diagnostic tools often does not allow us to recognise the true capabilities of a person and there are factors which often hinder the diagnostic process such as: the location of the examination (psychological and pedagogical counselling centre - a place not familiar to the child), specialists themselves (often lacking experience, a stranger from the perspective of the child), co-occurring neurological disorders (such as epilepsy, schizophrenia), and other disabilities (sight, hearing, movement, aphasia).

Therefore, both in classification and functional diagnosis, professionals do not have much choice, which we assume, may translate into the quality of the diagnoses 
and their content in terms of assessing the capabilities and needs of the child. For many years there have been debates in Poland about whether it would be better not to use psychological tests in the process of differential diagnosis of persons with profound intellectual disabilities, because the intelligence quotient is not an indicator of the actual functioning of these people or their resources. In the opinion of specialists, it would only make sense to use tools for functional assessment. As Ossowski (1999, p. 243) points out: ,a nosological or typological approach is based on the assumption of a simple and close relationship between personality traits and behaviour. This is related to the fatal legacy of somatic psychology which has suggested that physical characteristics should be used to infer personality and, consequently, behaviour. For this reason, the nosological typological diagnosis is the subject of particular criticism by rehabilitation psychology as it makes it too easy for the social environment to justify it's inactivity towards people with disabilities and to burden them for their life situation". However, given the structure of the system of support, education, and rehabilitation, this would require reconstruction and reorganisation of the operation of the health, education and legal sectors. This in turn is the responsibility of the powers that be (in this case the Polish Government).

Given these challenges, the need for more psychiatrists and neurologists is apparent to assist in the differential diagnosis and in the oversight of care for persons with profound intellectual disabilities in Poland. One confounding problem in the differential diagnosis process is that the neurological disorders that often co-occur with profound intellectual disabilities are not always detected and therefore are not always treated with pharmaceuticals. The symptoms of neurological disorders are also often misinterpreted and are perceived as difficult, aggressive behaviour or as self-aggression (Zijlstra \& Vlaskamp, 2005). For the sake of the well-being and quality of life of people with disabilities and their families, the medical, social, and educational sectors should cooperate a team, formed of: a doctor, educator, psychologist, and a social worker (without taking into account the order of the individual persons) (Hogg et al., 2007).

However, in practice this cooperation between specialists is often lacking in Poland (Lichtańska, 2019). Specialists in education and rehabilitation often find it difficult to interpret and link profound intellectual disabilities with neurological diseases, with the medicines taken or with diets, (though there are self-reports by many families as per their perceived link in some cases, there is insufficient scientific evidence to substantiate it), and therefore they are often unable to plan their treatment accordingly. What is lacking is an entity which might serve as a bridge which serves to build cooperation between these institutions, which the authors assume could solve the problem and thus have a positive impact on the lives of people with disabilities from childhood to maturity (Doody et al., 2019; Salvador-Carulla et al., 2013). The situation for professionals working with people with profound intellectual disabilities in rural towns and villages is dire where there is no access to trained specialists such as a neurologist or a psychiatrist as it pertains to differential diagnosis treatment. Thus, access to effective services applies above all to individuals with a disability who, due to their place of residence, resources, and family capacities, have only occasional medical consultations with psychiatrists, neurologists, or clinical psychologists.

In Poland, the professionals who are trained to work in educational and therapeutic institutions are special educators who are generally prepared to work with people with intellectual disabilities of various forms, degrees, including multiple disorders. However, research shows that teachers often do not feel competent, and the knowledge acquired during their studies is not sufficient for practice (Chrzanowska, 2015; Szumski, 2009). Therefore, we can see the need for master's studies, which in Poland last for 5 years, in a particular area that would entail more in-depth study of far-reaching problems. This results in a need for developing a new professional track, but funding would be a necessary stimulus to invoke such an initiative. However, given the low incidence of people with profound intellectual disabilities, this could result in there being little interest in this particular field of study which would not be financially viable for the state.

When a person with profound intellectual disabilities reaches the age of 25 , the first certificate confirming the need for revalidation classes, which indicates the degree of intellectual disability, expires, and only the other disability certificate remains which does not contain this provision. (The aim of the classes is to support the development of children and adolescents with profound intellectual disabilities, develop an interest in the environment and develop independence in functioning in everyday life, in accordance with their psychophysical abilities and individual developmental needs). This may be one of the reasons why there are no statistics on adults with profound intellectual disabilities in Poland. The country is struggling with the 
problem of providing education and rehabilitation, particularly for adults with profound intellectual disabilities who are often deprived of both education and participation in social life at this stage of their lives (Aksamit, 2019; Cytowska, 2011; Kowalik, 2001). In the next part of this study the legal changes that have taken place in the Polish education system with regard to people with profound intellectual disabilities will be analysed.

\section{EDUCATION AND REHABILITATION FOR PROFOUND INTELLECTUAL DISABILITIES}

The provision of the Constitution of the Republic of Poland of 2 April 1997 states: „Everyone has the right to education" (Polish Constitution Article 70). Another important document is the Act on the Educational System of 1991 (Journal of Laws of 1991, No. 95, item 425) which has also guaranteed education to every child in Poland regardless of their ability.

Despite this, people with profound intellectual disabilities have been absent from the educational space in practical terms. In reality they did not fulfill schooling obligations because they were massively exempted from it. In social discourse, they were described as „not promising". The only form of classes provided to people with profound intellectual disabilities at that time were activities which were based solely on care and, less often, on therapeutic activities stimulating development (Kopeć, 2007). Regardless of the fact that a certain group of people have been discriminated against by the Polish education system for years, and this is still to some extent the case, some aspects of this system have evolved. This is due to a number of factors, and we will point to those which we believe are significant in contributing to this.

Over the years, government styles have changed in Poland and each government has introduced new directives and law amendments governing the education system which are also being adapted to the European regulations and to global standards. The 1990s in Poland was a period of particularly large social changes; in accordance with the Standard Rules on the Equalization of Opportunities for Persons with Disabilities on 20 December 1993 (Resolution 48/96 annex), Poland undertook reforms of the education system in order to bring Poland closer to international standards.

A particularly important document for the educational beginnings of persons with profound intellectual disabi- lities was released in 1994. It was the year when the Act on Protection of Mental Health of 19 August 1994 was adopted (Journal of Laws of 1994, No. 111, item 535). The Act made it clear that education and revalidation classes should be organised for children and youth regardless of the degree of their disability, in particular in kindergartens, schools, care and educational institutions, rehabilitation and education centres, social welfare homes and health care institutions, as well as in the family home. It was a signal that there is a need to protect individual rights in the field of mental health of all Polish citizens, not only in theory, but also in practice. This Act, in the context of the aforementioned article, referred to as the Act of 7 September 1991 on the system of education which contains the following provision: The education system shall ensure in particular that every citizen of the Republic of Poland shall fulfil his or her right to education and the right of children and young people to education and adequate care to their age and development (Journal of Laws 1991, No. 95, item 425). This obliges the Ministry of Education to abandon the practice of exempting people with profound intellectual disabilities from compulsory schooling.

One might think that the introduction of statutes and regulations into the legal system means automatic changes resulting from their content but in practice, on 21 July 1995 , another law was passed changing the education system and some other laws (Journal of Laws of 1995, No. 101, item 504). This, for the first time in the history of Poland, in Article 16 (\$ 7-9) introduced a provision on persons with profound intellectual disabilities in the context of education. However, the actual change in practical terms did not take place until 1997, when the Ordinance of the Minister of National Education of 30 January 1997 on the principles of organising revalidation classes for children and young people with profound intellectual disabilities was issued (Journal of Laws of 1997, No. 14, item 76). This regulation, undoubtedly, paved the way to education for children with profound intellectual disabilities. That year, persons with profound intellectual disabilities first appeared in the education system not only in theory but also in practice. This regulation (Journal of Laws of 1997, No. 14, item 76) was the implementation of Article $(\$ 7.3)$ of the Mental Health Protection Act of 19 August 1994, which even obliged the Ministry of National Education to create a system of education and conditions for people with profound intellectual disabilities.

On the other hand, however, the above-mentioned statutes and regulations still denied the formal status of 
'pupils' to children with profound intellectual disabilities, calling them class participants instead. This practice still continues. Children with profound intellectual disabilities are the only group of children in the Polish education system who have always been denied the title of a pupil, which is a discriminatory practice. On 23 April 2013, the Regulation on the organisation of revalidation was replaced by a new Regulation of the Ministry of National Education on the conditions of the organisation of revalidation classes for children and young people with profound intellectual disabilities (Journal of Laws of 2013, item 579).

Despite the passage of time, the structure of the education system for people with profound disabilities has not changed much. This is the only regulation which is now binding in Poland regulating the education system for the group of people with profound intellectual disabilities. According to the binding Regulation of 1997 (Journal of Laws of 1997, No. 14, item 76) as well as that of 2013 (Journal of Laws of 2013, item 579) it is stated that children with profound intellectual disabilities shall be provided with revalidation classes on the basis of a certificate confirming the need for this.

In the Polish education system, classes for children with profound intellectual disabilities are organised from the beginning of the school year in the calendar year in which they turn three years old until the end of the school year in the calendar year in which they turn 25 years old (Journal of Laws of 2013, item 579). Participation in revalidation classes is considered to be a form of annual pre-school education which is compulsory schooling for people with profound intellectual disabilities. This means that in both kindergarten and at school, this group of children participate in revalidation classes without a curriculum or work plans imposed in advance by the Ministry as is the case with children with any other type and degree of intellectual disability in Poland. This is the only group of children for whom there is no curriculum framework or educational content to be achieved and realised in the Polish education system. On the one hand, this is due to the difficulty in predicting the developmental dynamics of a person with a given degree of intellectual disability, i.e., it is difficult to predict how much a particular individual is able to achieve due to his or her perception and cognitive abilities, or what his or her optimum level of ability is (Hale et al., 2007; Kielin \& Klimek-Markowicz, 2016). This is a process of education that is difficult to measure in terms of quality due to the complexity of profound intellectual disabilities (Forster \& Iacono, 2008).

\section{These revalidation classes, regardless of the child's chronological age or type of institution, include:}

- Learning to make contacts in a way appropriate to the needs and abilities of the participant

- Shaping the way of communicating with the environment at a level appropriate to the individual abilities of the participant.

- Motor and psychomotor improvement in the field of large and small motor skills, developing orientation in the diagram of one's own body and spatial orientation.

- Learning to achieve an optimal level of independence in basic spheres of life.

- Developing interest in the environment; multisensory learning, learning to understand the phenomena taking place, shaping the ability to function.

- Shaping the ability to cooperate within a group.

- Learning to act purposefully and in accordance with the participant's age, abilities, and interests, as well as his or her activity (Journal of Laws of 2013, item 579).

In addition to the areas mentioned above, around which the educational and therapeutic process is developed by specialists, an individual programme of revalidation classes is prepared for each child with profound intellectual disabilities which forms the basis for education and rehabilitation. The programme develops individual goals, methods, and forms of work, as well as the scope of cooperation with parents. Due to, for example, the state of health of a person with profound intellectual disabilities, in Poland revalidation classes can be held either in a team or individually, depending on the decision of the committee confirming the need for special education. The difference between these two options is the number of revalidation classes and it has been legally specified that in the case of team meetings, each participant has 20 hours per week, but no more than 6 hours per day but in the case of individual classes, on the other hand, 10 hours per week, but no more than 4 hours per day. Classes are conducted in small groups; it is specified in the cited regulation that a team consists of only 2 to 4 participants (Journal of Laws of 2013, item 579).

The education of persons with profound intellectual disabilities is part of the education system in Poland. The legal acts on special education that have been developed over the years only mention profound intellectual disabilities. For example, in the Ordinance of the Minister of National Education of 9 August 2017 on the rules for organisation and provision of psychological and educational support in public nursery schools, schools and edu- 
cational institutions, (Journal of Laws of 2017, item 1591), a division is visible between students and children with disabilities to whom a certificate confirming the need for special education is issued, while people with profound disabilities are referred to as "children” and "youths". There are only vague mentions in these provisions resulting in ambiguity and difficulty in interpreting various legal acts in relation to the educational reality of people with profound intellectual disabilities. Secondly, this does not prompt decision-makers at state level in the education system to introduce changes in spite of the fact that it is a discriminatory practice.

Despite the ratification and the adoption by Poland of many global directives concerning, inter alia, human rights, and in particular, the Convention on the Rights of Persons with Disabilities, (Journal of Laws of 2012, item 1169), where Article 24 provides that equal access to education should be ensured, national law continues to discriminate against people with profound intellectual disabilities. Regardless of the type of disability, everybody should be provided equal access to the education system, however, the extent to which a particular person will be able to benefit from it depends on such person's psychological functioning and should be the second-level determinant for the course of education and not the first-level determinant.

In practice, revalidation classes in Poland are based on sensory stimulation. Various approaches and trends are applied: psychoanalytic, behavioural and those based on a more humanistic approach. It is impossible to assess the prevailing approaches in working with people with profound intellectual disabilities in Poland because of the lack of research in this area (Gawlik \& Gomola, 2018). Given the lack of evidence-based practices, this allows practitioners to provide services in an unregulated manner. This degree of freedom and flexibility for practitioners means that commonly used therapeutic methods are not only adapted to: the needs and possibilities, the state of health due to co-occurring disorders and diseases, (one of the most frequent is epilepsy which forces specialists to adjust stimulation so as to avoid seizures), but also to the financial standing of a particular institution.

\section{A MODEL OF INTEGRATED AND INCLUSIVE EDUCATION AND PROFOUND INTELLECTUAL DISABILITY}

In Poland, as in many other countries, the tendency was for parents to place their children with various disabilities in special schools and this trend prevailed for a long time. This had begun to change gradually by the early 1990s, when parents started to fight for equal access to education for children with disabilities by making the first attempts at inclusive education. The prevailing practice in Poland now is that children with more severe disabilities attend special schools. It is rare for a child with a mild intellectual disability to attend special school.

There has been a marked increase in the numbers of students with autism, Asperger's Syndrome, Down Syndrome and also with moderate intellectual disabilities in regular schools (Bąbka, 2015; Dudzińska \& Roszewska, 2016; Sadowska, 2016). Special education in Poland, regardless of the type and degree of disability, can take place in special, integrated, or regular (inclusive) institutions which is guaranteed by the Ordinance of the Minister of National Education of 9 August 2017 on the conditions for the provision of education and care of children and young people who are disabled, socially maladjusted or at risk of social maladjustment (Journal of Laws of 2017, item 1578). Educational and therapeutic institutions in Poland (early intervention centres, kindergartens, schools) may be state-owned (public) or run by private sector entities (non-public).

The latter sector is usually run by non-profit organisations, (foundations, associations), but some of them are run by parents independently. The decision concerning the type of institution to be attended by the child, (special, integrated, or inclusive education), at each stage of education in Poland is made by the parent. To a certain extent, this also applies to children and adults with profound intellectual disabilities. In Poland, there are also: private kindergartens, schools, day centres and permanent residence centres for people with profound intellectual disabilities. However, the problem is the fees which parents are obliged to pay if they choose private institutions. The range of these fees varies depending on, among other things, the age group for which education and rehabilitation is offered, the scope and type of treatment, but the fees in such centres are highest for adults with profound intellectual disabilities. The Polish State does not subsidise parents. Often, such institutions are also run by Non- 
Governmental Organizations (NGO's). However, this has little impact on the range of fees for education and rehabilitation provided there. Therefore, very often only wealthy families can afford this type of facility.

\section{PUBLIC REGULAR SCHOOL - WORKING TOWARDS INTEGRATED AND INCLUSIVE EDUCATION}

Regular and integrated institutions are encouraged by the Polish State to admit children with different types and forms of disability. However, it is not practised in Poland that the process of education and rehabilitation of people with profound intellectual disabilities takes place in institutions following the integrated and inclusive model. Only a few parents choose the non-public education system and decide to provide their child with education in an integrated and inclusive system. The parents who would like their child to be educated within a regular institution, such as kindergarten and school, are in a particularly difficult situation.

From a legal point of view, parents are entitled to expect this (Journal of Laws of 2017, item 1578), however, in practice things look vastly different. Admission of these children is most often refused by the headmaster of the institution due to the lack of specialists, specialised space for therapeutic and nursing treatments, architectural space of the building, and lack of teachers prepared to work with children with disabilities. These practices are rare, because there is a top-down assumption in Poland that special schools are the most suitable place for the education of children with profound intellectual disabilities. This does not arouse much public opposition, not even among parents.

Once again, people with profound disabilities from rural areas are in the most difficult situation, because there are not always special schools in their area, and they are sometimes a great distance away. In practice, in such a situation the child is offered individual classes despite the fact that his or her state of health would allow them to participate in team activities. From a legal standpoint, the child fulfills schooling obligations and receives education, however, such practices are also an example of inequality in terms of access to education while equality is supposedly guaranteed under Polish and European laws. There are also known cases of resentment expressed by the parents of healthy children in Poland (Mihilewicz, 2003) and abroad (de Boer et al., 2010). In practical terms, the- se models of teaching are still not available to people with profound intellectual disabilities in Poland.

\section{THE REALITY OF EDUCATION AND REHABILITATION OF ADULTS WITH PROFOUND INTELLECTUAL DISABILITIES}

The specificity and complexity of profound intellectual disabilities in Poland, but also worldwide, determined the mortality of this group of people at an early age (Kościelska, 1985; Patja et al., 2000). Over the years, however, the life expectancy for people with profound intellectual disabilities has significantly increased. Nonetheless, the system of education for this group of people in Poland has not followed this growth in the context of improvement and development nor taking into account, for example, the importance of lifelong education and not just to a certain age. This is a particularly visible difference when compared to other countries and the solutions applied by them.

In Poland, policy has moved away from institutionalisation due to incidents which occurred in these centres; the practices applied, the quality of life and the funding by the state all took away subjectivity and dignity for those who resided therein. However, it can be seen that, to a large extent, this state of affairs was due to the human factor; in particular, the approach and practices of the professionals working there as well as the system of care and support that prevailed there. We assume that the best environment for every person is the family home, the support of their loved ones. However, the question arises: when closing large care institutions in Poland, was there an alternative presented for people with profound intellectual disabilities? One of them was the family home, another was day care centres or projects carried out by, among others, NGOS. In practice, however, research shows that these alternatives do not work as assumed in theory. In other words, they do not fully meet their needs, also in the context of the quality of life, of people with profound intellectual disabilities and their carers (Aksamit, 2019; Cytowska, 2017). With regard to the family home situation, research conducted within a group of mothers of adults with profound intellectual disabilities has shown that women are in a particularly difficult psychological and financial situation.

Poland is a country where a parent who receives childcare benefits cannot combine this income with any gainful employment. Therefore, in order to support their 
children, the majority of parents, especially mothers, do not take up employment or continue to work until the child reaches the age of 25 (the moment when the broadly defined education in the Ministry of Education system ends) (Aksamit, 2019). This is a particularly difficult stage for many families who are looking for day centres or projects in which their adult children might participate.

\section{The facilities offering day care for people with profo- und intellectual disabilities in Poland include (naming just those which actually exist in practical terms and are not just, a dead letter'):}

- Community Self-help Homes - day care centres with the following tasks: developing and maintaining skills necessary in everyday life; activating participants; developing individual talents; expanding independence and life resourcefulness adjusted to the individual psychological and physical situation of a participant. In such institutions, therapy takes the form of workshops which include household, art, music, sewing and knitting, carpentry etc. In terms of practical experience, it can be noted that it is often the case that the offer for an adult with intellectual disabilities is inadequate and unsuitable, since most of the participants are people with moderate or severe intellectual disabilities. These community self-help homes are often overcrowded and there is no room for individual development. There are participants who have been spending full days in a sewing and knitting workshop for years but have never even used a needle and thread (Journal of Laws of 2010, No. 238, item 1586).

- Occupational Therapy Workshops - meant to develop and maintain the abilities needed in everyday life and social contacts in the group of people with disabilities. Therapy in these centres consists of improving self-service skills (personal hygiene, cleaning, meal preparation, shopping, etc.) and the development of individual interests, artistic, musical and entertainment talents, preparation for the profession and for work (Journal of Laws of 2004, No. 63, item 587). In the case of people with profound disabilities, this is often the only place where they can be among people and not locked up in their family homes but the therapy is not adapted to the actual needs of people with profound intellectual disabilities. From the parents' perspective, this is often one of the possible solutions, although these institutions in Poland are also overcrowded (Aksamit, 2019).

- Social Care Homes - these are 24-hour permanent residence institutions which, as studies show, are the last resort in the opinion of mothers of adults with profound intellectual disabilities (Aksamit, 2019). The histo- ry of the functioning of many Polish social care homes is entangled in many negative experiences and stories: inhumane treatment of people living there, harassment, physical and emotional abuse.

- The designed form of support is the ,Safe Future for People with Intellectual Disabilities' model which consists of building ,circles of support' around a person with intellectual disabilities. The circle of support is made up of their loved ones, trusted people, family friends and institutions familiar to the person with intellectual disabilities. The model seeks to develop solutions for the legal, financial, and social security situation of a person with intellectual disabilities for the time when, for natural reasons, he or she will no longer have family support. This can be achieved by preparing the person with disabilities and her or his environment in a way that enables them to function safely in their local community, based on the concept of support circles [https://kregiwsparcia. $\mathrm{pl} /$ - accessed 16 February 2021].

The first practical problem is the number of these institutions. In large cities, their network is extensive, although parents still often have to wait until a place is vacated. However, the largest problem is small towns and villages where such institutions do not exist or are overcrowded. Another problematic aspect is that, due to the complexity of the functioning of people with profound intellectual disabilities, institutions are sometimes not able to provide accommodation for them. The third and final alternative we will mention are the projects carried out by non-profit organisations or by state organisations (local governments, municipalities). In practice, however, they hardly ever include people with profound intellectual disabilities. The project activities most often involve care, voluntary work for the person with profound intellectual disabilities and for the person's family and they are limited in time. Research has shown that voluntary workers very often give up because of a sense of fear when faced with the complexity of the functioning of persons with profound intellectual disabilities (Aksamit, 2019).

Despite these most popularly selected alternatives for adults with profound intellectual disabilities in Poland, a lot of people are confined to their family homes if they are over the age of 25 . Thus, it is often the case that a parent who took up work when the child was subject to the education and rehabilitation offered by the Ministry of National Education, has to give up employment. One of the parents, most often the mother as research shows, faces the situation where they become the sole form of 
support for their child or children with profound intellectual disabilities when they turn 25. It is often the case that parents return to the past emotional crises they had experienced during the initial stages of parenting children with profound intellectual disabilities (Dillenburger, $\&$ McKerr, 2010). The feelings of grief, shame, and lack of fulfillment, which have changed in their intensity over the years, often return and the level of anxiety and fear for the future increases (Bindels-de Heus et al., 2013; Gołubiew-Konieczna, 2016). This is accompanied by a feeling of powerlessness about the vision of the future. Due to the lack of systemic solutions at state level which, regardless of the state of health, specificity and complexity of the disability, place of residence and material situation, would include people with profound intellectual disabilities.

It is shown from the research carried out in the group of mothers of adult people with profound intellectual disability and the pilot research in the group of fathers, (the pilot was carried out as part of the project financed by the Maria Grzegorzewska University), that the situation becomes more complicated when the family cannot afford medical treatment which cannot be avoided in the case of people with profound intellectual disabilities. This is particularly true of families living in rural areas because health care institutions which can admit people with intellectual disabilities are far away and there are no specialised doctors (neurologists, psychiatrists) who have experience with people with a specific disability. Because of a lack of therapeutic facilities, people with profound intellectual disabilities are often placed in psychiatric wards for any kind of disorder even if general health care and treatment are required and not just psychiatric treatment (Aksamit, 2019).

NGOs play an important role in supporting people with profound intellectual disabilities. In Poland, they provide early developmental support, run kindergartens, schools, revalidation, rehabilitation, and education centres and centres for adults with disabilities. These organisations also deal with non-systemic therapy for children with disabilities and their parents. These activities are often free of charge or are financially more accessible to parents compared to other private sector facilities. Most NGOs provide support not only to individuals with disabilities, but also to their families. NGOs are among the few institutions in Poland attempting to support adults with profound intellectual disabilities and their families. They do it, for example, by running day care centres, rehabilitation holidays, counselling and training for parents as well as legal and psychological assistance. There are attempts to imple- ment projects aimed at social and professional activation, however, this is usually only the case in large cities where they provide short-term activities, (several times a week for an hour), and psychological assistance for parents. Most of these activities are free of charge for parents but, once again, research shows that such activities are lacking, particularly in small towns and villages in Poland. In addition, as shown by research, the social security system does not provide for all basic needs such as food, medicines, and fees, in the opinion of the mothers of adults with profound intellectual disabilities (Aksamit, 2019).

\section{CONCLUSION}

Due to the "absent" status of people with profound intellectual disabilities which has persisted for years, the literature does not contain extensive research in this area in Poland (Kwiatkowska, 1997; Olechnowicz, 1994; Piszczek, 2006). Today, a similar situation, where the interest of researchers in Poland is negligible compared to their focus on profound intellectual disabilities and autism, adulthood of people with autism, mild and moderate intellectual disabilities versus profound intellectual disabilities. The group of people with profound disabilities both in Poland and worldwide is a minority, yet this does not mean that this group can be ignored in social and scientific discourse (Schalock et al., 2010). A particular problem in the context of undertaking research in the area of profound intellectual disabilities concerns the issue of their financing in Poland. The most frequent opinion in the reviews of submitted research projects is that, due to the group size in Poland, research results are not going to contribute much to the progress of science and the scientific discipline represented by the author.

The analysis carried out by the authors in this paper indicates that access to education is ensured in Poland, however, in its structure it is differentiated to the detriment of people with the most severe forms of disability (Kielin \& Klimek-Markowicz, 2016; Kopeć, 2004). Lifelong education and rehabilitation remain a theoretical slogan for many adults with profound intellectual disabilities (Aksamit, 2019). In legal theory, the Polish rehabilitation system provides access to rehabilitation for adults with profound intellectual disabilities and includes the education process. In practice, however, it is available only to a selected group of people with profound intellectual disabilities whereas people from rural areas are particularly vulnerable to exclusion from this accessibility. 
The educational situation of people with profound intellectual disabilities is not evolving, unlike that of other disabilities. The support received by people with profound intellectual disabilities is not validated or developed and does not take into account the transversal needs of this group. This is contrary to, for example, the assumptions of the Convention of the United Nations on the Rights of People with Disabilities (Journal of Laws of 2012, item 1169), and the Convention, adopted by Poland in 2012, is, in fact, it's international obligation. Therefore, in order to change constituents of the reality faced in education by people with profound intellectual disabilities, it is necessary, above all, to take into account that disability is a phenomenon that requires many interpretations (Clement $\&$ Bigby, 2009). Thus, collaboration between the medical, legal, educational, and social sectors is of utmost importance. Everybody has the right to education regardless of their age, gender, race, or disability. In case of people with profound disabilities, rehabilitation of the individual is also necessary for education to take place. This should be implemented in practice, in order to also include the least numerous groups, i.e., children, young people and adults with the most severe forms of intellectual disabilities. If we want a change, the decision-makers at state level must understand what profound intellectual disability means for an individual, including the situation faced by this group of people in different dimensions of their lives, and especially that this is often determined by state policy and the attitude of society (Nakken \& Vlaskamp, 2007).

Recommendations for change include the development of education and rehabilitation facilities not only located in special schools, but also those providing education in an integrated and inclusive model. Changes are needed not only in interpreting at state level what profound intellectual disability is, but furthermore in public awareness of the potential and abilities of people with profound intellectual disabilities. These abilities and potential will often only be visible if under the condition of a positive attitude. We need to change the social lens through which we perceive people with profound intellectual disabilities from childhood to maturity. People with profound intellectual disabilities are particularly vulnerable as they are voiceless on many issues which affect them, as a result their perspective is unknown.

The need for support in different areas of life and dependence on other people makes the concept of autonomy an relatively unknown topic in this area, and yet particularly important (Wehmeyer \& Garner, 2003). The lack of perspective regarding people with profound disabilities makes them completely dependent on the decisions of others in various areas and dimensions of their lives. In spite of this difficult situation, there is a light at the end of the tunnel. The efforts of parents over the years have been effective in including this group of children, youths and adults in the education system, making parents' voices heard as advocates for the rights of people with profound intellectual disabilities and thereby further raising public awareness. Profound intellectual disability is not only the problem of the person affected by it or the person's family, but also a social problem for which every member of the community is responsible.

\section{ACKNOWLEDGEMENT}

None.

\section{DISCLOSURE STATEMENT}

No potential conflict of interest was reported by the authors.

\section{FUNDING}

Thanks for the inspiration of the teachers and other specialists working with people who possess profound intellectual disabilities and for the support provided by the Maria Grzegorzewska University.

\section{REFERENCES}

Act of 19th August 1994 on the Protection of Mental Health (Journal of Laws, No. 111, item535). Polish Legal Acts. https://isap.sejm.gov.pl/isap.nsf/DocDetails.xsp?id=WDU19941110535

Act of 21 st July 1995 to amend the Act on the Educational System as Well as Some Other Acts (Journal of Law of 1995, No. 101, item. 504).

Polish Legal Acts. http://isap.sejm.gov.pl/isap.nsf/DocDetails.xsp?id=WDU19951010504

Act of 27th August 1997 on Vocational and Social Rehabilitation and Employment of Persons with Disabilities (Journal of Laws of 1997, No. 123, item 776). Polish Legal Acts. http://isap.sejm.gov.pl/isap.nsf/DocDetails.xsp?id=WDU19971230776

Act of 7th September 1991 on the Educational System (Journal of Laws 1991, No. 95, item 425). Polish Legal Acts. https://isap.sejm.gov.pl/isap.nsf/DocDetails.xsp?id=WDU19910950425

Announcement of the Marshal of the Sejm of the Republic of Poland of February 13th 2020 on the Announcement of the Text on Vocational and Social Rehabilitation and Employment of Disabled People (Journal of Laws 2020, item 426). Polish Legal Acts. http://isap.sejm.gov.pl/isap.nsf/DocDetails.xsp?id=WDU20200000426

Aksamit, D. (2019). Kobiety-Matki o macierzyństwie. Socjopedagogiczne studium narracji matek dorosłych osób z głęboką niepełnosprawnością intelektualną. Maria Grzegorzewska University Press. 
Arvio, M., \& Sillanpää, M. (2003). Prevalence, aetiology and comorbidity of severe and profound intellectual disability in Finland. Journal of Intellectual Disability Research, 47, 108-112. https://doi.org/10.1046/j.1365-2788.2003.00447.x

Babbie, E. R. (2008). The Basics of Social Research. Thomson/Wadsworth.

Bąbka, J. (2015). Edukacja osób z niepełnosprawnością w systemie niesegregacyjnym - wykluczające czy dopełniające się formy kształcenia. Interdyscyplinarne Konteksty Pedagogiki Specjalnej, 11, 9-34. https://doi.org/10.14746/ikps.2015.11.01

Bindels-de Heus, K. G. C. B., van Staa, A., van Vliet, I., Ewals, F. V. P. M., \& Hilberink, S. R. (2013). Transferring young people with profound intellectual and multiple disabilities from pediatric to adult medical care: parents' experiences and recommendations. Intellectual and Developmental Disabilities, 51(3), 176-189. https://doi.org/10.1352/1934-9556-51.3.176

Bronfenbrenner, U. (1974). Developmental research, public policy, and the ecology of childhood. Child Development, 45, 1-5. https://doi.org/10.2307/1127743

Bronfenbrenner, U. (1975). Reality and research in the ecology of human development. Proceedings of the American Philosophical Society, 119, 439-469. https://doi.org/10.1037/0003-066X.32.7.513

Bronfenbrenner, U. (1989). Ecological systems theory. Annals of Child Development, 6, 187-249.

Bronfenbrenner, U., \& Morris, P. A. (1998). The ecology of development processes. In W. Damon (Series Eds.) \& R. M. Lerner (Vol. Eds.), Handbook of child psychology: Vol. 1. Theoretical models of human development (pp. 993-1027). John Wiley \& Sons.

Chrzanowska, I. (2015). Pedagogika Specjalna. Od tradycji do współczesności. Oficyna Wydawnicza Impuls.

Cierpiałkowska, L. (2007). Psychopatologia. Wydawnictwo Naukowe Scholar.

Clement, T., \& Bigby, C. (2009). Breaking out of a distinct social space: reflections on supporting community participation for people with severe and profound intellectual disability. Journal of Applied Research in Intellectual Disabilities, 22(3), 264-275. https://doi.org/10.1111/j.1468-3148.2008.00458.x

Convention of the United Nations on the Rights of People with Disabilities of 2006, ratified by Poland in 2012 (Journal of Laws of 2012, item 1169). Polish Legal Acts. http://isap.sejm.gov.pl/isap.nsf/DocDetails.xsp?id=WDU20120001169\&type=2

Cytowska, B. (2011). Rodzice wobec dorosłości swoich dzieci z niepelnosprawnością intelektualną. In S. Walasek, B. Winczura (Eds.), Wychowanie w rodzinie. Rodzin o specjalnych potrzebach (Vol. 4., pp. 87-107). The Karkonosze State University Press.

Cytowska, B. (2017). Ojcowie wobec opieki nad dziećmi z głęboką niepełnosprawnością intelektualną i ich edukacji - studium etnograficzne. Człowiek. Niepełnosprawność. Społeczeństwo, 2(36), 89-112. https://doi.org/ 10.5604/01.3001.0010.5203

de Boer, A., Pijl, S. J., \& Minnaert, A. (2010). Attitudes of parents towards inclusive education: a review of the literature. European Journal of Special Needs Education, 25(2), 165-181. https://doi.org/10.1080/08856251003658694

Dillenburger, K., \& McKerr, L. (2010). "How long are we able to go on?" Issues faced by older family caregivers of adults with disabilities. British Journal of Learning Disabilities, 39(1), 29-38. https://doi.org/10.1111/j.1468-3156.2010.00613.x

Doody, O. (2011). Families' views on their relatives with intellectual disability moving froma long stay psychiatric institution to a community based intellectual disability service: An Irish context. British Journal of Learning Disabilities, 40, 46-54. https://doi.org/10.1111/j.1468-3156.2011.00682.x

Doody, O., Slevin, E., \& Taggart, L. (2019). A survey of nurses and multidisciplinary team members' perspectives on the perceived contribution of intellectual disability clinical nurse specialists. Journal of Clinical Nursing, 28, 3879-3889. https://doi.org/10.1111/jocn.14990

Dudzińska, A., \& Roszewska, K. (2016). Praktyczna realizacja polityki oświatowej wobec uczniów z niepełnosprawnościami. Niepełnosprawność. Dyskursy Pedagogiki Specjalnej, 22, 185-201.

Flick, U. (2011) Mixing methods, triangulation and integrated research: Challenges for qualitative research in a world of crisis. In N. K Denzin, \& M. Giardina (Eds.), Qualitative inquiry and global crises (pp. 132-152). Left Coast Press.

Forster, S., \& lacono, T. (2008). Disability support workers' experience of interaction with a person with profound intellectual disability. Journal of Intellectual \& Developmental Disability, 33(2), 137-147. https://10.1080/13668250802094216

Frączek, P., Jabłońska, M., \& Pawlikowski, J. (2013). Medyczne, etyczne, prawne i społeczne aspekty badań prenatalnych w Polsce. Medycyna Ogólna i Nauki o Zdrowiu, 2, 103 -109. http://orcid.org/0000-0003-4271-8478

Fullerton, A., Douglass, M., \& Dodder, R. A. (1999). A reliability study of measures assessing theimpact of deinstitutionalization. Research in Developmental Disabilities, 20(6), 387-400. https://doi.org/10.1016/s0891-4222(99)00020-7

Gawlik, E., \& Gomola, J. (2018). Rzeczywistość edukacyjna osób z głęboką niepełnosprawnością intelektualną. Zeszyty Naukowe Wyższej Szkoły Humanitas. Pedagogika, 16, 203-212.

Geertz, C. (2000). Available light: anthropological reflections on philosophical topics. Princeton University Press.

Gołubiew-Konieczna, M. (2016). Wspieranie osób z głębszą i głęboką niepełnosprawnością intelektualną i ich rodziców w drodze przez całe życie na przykładzie działalności Polskiego Stowarzyszenia na rzecz Osób z Upośledzeniem Umysłowym, koło w Gdańsku. Niepełnosprawność, 24, 169-182. https://doi.org/10.4467/25439561.NP.16.011.6837

Hale, L., Bray, A., \& Littmann, A. (2007). Assessing the balance capabilities of people with profound intellectual disabilities who have experienced a fall. Journal of Intellectual Disability Research, 51, 260-268. https://doi.org/10.1111/j.1365-2788.2006.00873.x

Hogg, J., Juhlberg, K., \& Lambe, L. (2007). Policy, service pathways and mortality: a 10-year longitudinal study of people with profound intellectual and multiple disabilities. Journal of Intellectual Disability Research, 51, 366-376. https://doi.org/10.1111/j.1365-2788.2006.00884.x

Jankiewicz, A., Skrypnik, D., \& Skrypnik, K. (2014). Głęboka niepełnosprawność intelektualna a rozwój emocjonalno-społeczny i motoryczny. Psychiatria, 11,(4), 222-227.

Kielin, J. (2002). Profil osiągnięć ucznia. Przewodnik dla nauczycieli i terapeutów. Gdańskie Wydawnictwo Psychologiczne.

Kielin, J., \& Klimek-Markowicz, K. (2016). Krok po kroku. Nauczanie i terapia dzieci z umiarkowaną, znaczną i głęboką niepełnosprawnością intelektualną. Gdańskie Wydawnictwo Psychologiczne.

Kopeć, D. (2004). Dylematy etyczne pojawiające się w procesie rehabilitacji osób z niepelnosprawnością intelektualną. In J. Głodkowska, A. Giryński (Eds.), Osobowość, samorealizacja, odpowiedzialność, bezpieczeństwo, autonomia. Teoria, empiria i praktyka w rehabilitacji osób z niepełnosprawnością umysłową od dzieciństwa do późnej dorosłości (pp.79-87). Maria Grzegorzewska University Press.

Kopeć, D. (2007). Osoba z głęboką niepełnosprawnością intelektualną w systemie edukacji. In Z. Janiszewska-Nieścioruk (Eds.), Problemy edukacji integracyjnej dzieci i młodzieży z niepełnosprawnością intelektualną (pp.133-145). Oficyna Wydawnicza Impuls.

Kopeć, D. (2013). Rzeczywistość (nie)edukacyjna osoby z głęboką niepełnosprawnością intelektualna. Zbiorowe instrumentalne studium przypadku. Adam Mickiewicz University Press.

Kościelska, M. (1985). Odpowiedzialni rodzice. Oficyna Wydawnicza Impuls.

Kowalik, S. (2001). Pomiędzy dyskryminacją a integracją osób niepełnosprawnych. In B. Kaja (Eds.), Wspomaganie rozwoju. Psychostymulacja i psychokorekcja (Vol.3., pp. 36-58). Wydawnictwo Uczelniane Akademii Bydgoskiej. 
Krause, A. (2010). Współczesne paradygmaty pedagogiki specjalnej. Oficyna Wydawnicza Impuls.

Kręgi wsparcia. (2021, February 16). https://kregiwsparcia.pl/

Kwiatkowska, M. (1997). Dzieci głęboko niezrozumiane. Oficyna Literatów i Dziennikarzy „,Pod Wiatr”.

Lichtańska, K. (2019). Opinie rodziców na temat jakości współpracy oraz wsparcia uzyskiwanego w procesie terapeutycznym ich dziecka z niepełnosprawnością. Raport z badań. Kwartalnik Pedagogiczny, 64 (2 (252)), 271-283. https://doi.org/10.5604/01.3001.0013.3662

Marcinkowska, B. (2012). Kwestionariusz oceny sposobów komunikacji osób z głębszą niepełnosprawnością intelektualną (KOSK) - propozycja techniki diagnostycznej, ocena psychometryczna. Człowiek Niepełnosprawność Społeczeństwo, 2, 51-66.

Marcinkowska, B. (2013). Model kompetencji komunikacyjnych osób z głębszą niepełnosprawnością intelektualną. Maria Grzegorzewska University Press.

Marcinkowska, B. (2017). Zagubieni w przestrzeni społecznej - rozważania nad postrzępionym światem osób głęboko niezrozumianych. In J. Głodkowska (Eds.), Personalistyczne ujęcie fenomenu niepełnosprawności (pp.131-151). Maria Grzegorzewska University Press.

Mihilewicz, S. (2003). Postrzeganie integracji przez rodziców dzieci sprawnych i niepełnosprawnych. In Z. Kazanowski, D. Osik-Chudowolska (Eds.), Integracja osób niepełnosprawnych w edukacji i integracjach społecznych (pp. 333-340). Maria Curie-Skłodowska University Press. Nakken, H., \& Vlaskamp, C. (2007). A Need for a Taxonomy for Profound Intellectual and Multiple Disabilities. Journal of Policy and Practice in Intellectual Disabilities, 4(2), 83-87. https://doi.org/10.1111/j.1741-1130.2007.00104.x

Olechnowicz, H. (1994). Wyzwalanie aktywności dzieci głębiej upośledzonych umysłowo. Wydawnictwa Szkolne i Pedagogiczne.

Orkisz, M., Piszczek, A., Smyczek, J., \& Szwiec, J. (Eds.). (2008). Edukacja uczniów z głębokim upośledzeniem umysłowy: przewodnik dla nauczycieli. Centrum Metodyczne Pomocy Psychologiczno-Pedagogicznej MEN.

Ossowski, R. (1999). Teoretyczne i praktyczne podstawy rehabilitacji. Wydawnictwo Uczelniane WSP.

Patja, K., livanainen, M., Vesala, H., Oksanen, H., \& Ruoppila, I. (2000). Life expectancy of people with intellectual disability: a 35-year follow-up study. Journal of Intellectual Disability Research, 44(5), 591-599. https://doi.org/10.1046/j.1365-2788.2000.00280.x

Piszczek, M. (1997). Zagadnienia prawno-organizacyjne związane z realizacją rozporządzenia MEN z dnia 30 stycznia 1997 (o organizacji zajęć rewalidacyjno-wychowawczych). Rewalidacja, 2, 78-83.

Piszczek, M. (2006). Dziecko, którego rozwój emocjonalno-poznawczy nie przekracza pierwszego roku życia. Diagnoza, zasady terapii i ocena efektów zajęć. Centrum Metodyczne Pomocy Psychologiczno-Pedagogicznej MEN.

Prysak, D. (2015). Codzienność osoby z głęboką niepełnosprawnością intelektualną w domu pomocy społecznej. University of Silesia Press

Regulation of the Minister of Economy, Labour and Social Policy of 25 March 2004 Concerning Occupational Therapy Workshops (Journal of Laws of 2004, No. 63, item. 587). Polish Legal Acts. http://isap.sejm.gov.pl/isap.nsf/DocDetails.xsp?id=wdu20040630587

Regulation of the Minister of Labor and Social Policy of 9 December 2010 on Environmental Self-help Houses (Journal of Laws of 2010, No. 238, item 1586). Polish Legal Acts. http://isap.sejm.gov.pl/isap.nsf/DocDetails.xsp?id=wdu20102381586

Regulation of the Minister of National Education of 23 April 2013 on the Terms and Methods of Organisation of Revalidation and Education Activities for Children and Young People with Profound Intellectual Disabilities (Journal of Laws of 2013, item 529). Polish Legal Acts. http://isap.sejm.gov.pl/isap.nst/DocDetails.xsp?id=wdu20130000529

Regulation of the Minister of National Education of 24 August 2017 on Organizing Early Childhood Development Support (Journal of Laws 2017, item 1635). Polish Legal Acts. http://isap.sejm.gov.pl/isap.nsf/DocDetails.xsp?id=WDU20170001635

Regulation of the Minister of National Education of 30 January 1997 on the Terms and Methods of Organisation of Revalidation and Education Activities for Children and Young People with Profound Intellectual Disabilities (Journal of Laws of 1997, No. 14, item 76). Polish Legal Acts. http://isap.sejm.gov.pl/isap.nsf/DocDetails.xsp?id=WDU19970140076

Regulation of the Minister of National Education of 7 September 2017 on Certificates and Statements Issued by Assessment Committees at Public Counselling and Guidance Centres (Journal of Laws of 2017 item 1743). Polish Legal Acts. http://isap.sejm.gov.pl/isap.nsf/DocDetails.xsp?id=WDU20170001743

Regulation of the Minister of National Education of 9 August 2017 on the Rules for Organisation and Provision of Psychological and Educational Support in Public Nursery Schools, Schools and Educational Institutions (Journal of Laws of 2017, item 1591). Polish Legal Acts. http://isap.sejm.gov.pl/isap.nsf/DocDetails.xsp?id=WDU20170001591\&SessionID=4A641DF950F06FAD7A0C704E5C65A506437C58A0

Regulation of the Minister of National Education of 9 August 2017 on The Conditions for The Provision of Education and Care to Children and Young People Who are Disabled, Socially Maladjusted or at Risk of Social Maladjustment (Journal of Laws of 2017, item 1578). Polish Legal Acts. http://isap.sejm.gov.pl/isap.nsf/DocDetails.xsp?id=WDU20170001578

Sadowska, S. (2016). Polityka oświatowa w rozwiązywaniu kwestii kształcenia uczniów z niepełnosprawnościami (1989-2016). Niepełnosprawność. Dyskursy Pedagogiki Specjalnej, 22, 13-36.

Salvador-Carulla, L., García-Gutiérrez, J. C., Ruiz Gutiérrez-Colosía, M., Artigas-Pallarès, J., García lbáñez, J., González Pérez, J., \& Martínez-Leal, R. (2013). Borderline Intellectual Functioning: Consensus and good practice guidelines. Revista de Psiquiatría y Salud Mental (English Edition), 6(3), 109-120. https://doi.org/10.1016/..rpsm.2012.12.001

Schalock, R. L., Buntinx, W. H. E., Borthwick-Duffy, S., Bradley, V., Craig, E. M., Coulter, D. L., \& Yeager, M. H. (2010). Intellectual disability: Definition, classification, and system of supports (11e). American Association on Intellectual and Developmental Disabilities.

Standard Rules on the Equalization of Opportunities for Persons with Disabilities on 20 December 1993 (resolution 48/96 annex). https://www.un.org/development/desa/disabilities/standard-rules-on-the-equalization-of-opportunities-for-persons-with-disabilities.html

Szumski, G. (2009). Integracyjne kształcenie niepełnosprawnych: sens i granice zmiany edukacyjnej. Wydawnictwo Naukowe PWN.

The Constitution of the Republic of Poland of 2 April 1997 (Journal of Laws of 1997, No. 78, item 483). Polish Legal Acts. https://www.sejm.gov.pl/prawo/konst/angielski/konse.htm

UN General Assembly, Standard rules on the equalization of opportunities for persons with disabilities: resolution/adopted by the General Assembly, 20 December 1993, A/RES/48/96. https://www.refworld.org/docid/3b00f2e80.html

Wehmeyer, M. L., \& Garner, N. W. (2003). The Impact of Personal Characteristics of People with Intellectual and Developmental Disability on Self-determination and Autonomous Functioning. Journal of Applied Research in Intellectual Disabilities, 16(4), 255-265. https://doi.org/10.1046/j.1468-3148.2003.00161.x

Witkowski, T. (1988). Podręcznik do inwentarza PPAC Gunzburga do oceny postępu w rozwoju społecznym upośledzonych umysłowo. COMPWZ MEN.

Wrona, S. (2011). Osoba głęboko upośledzona umysłowo w systemie edukacji - analiza porównawcza zajęć rewalidacyjno-wychowawczych. Oficyna Wydawnicza Impuls.

Zijlstra, H. P., \& Vlaskamp, C. (2005). The impact of medicalhealthconditions of children withprofoundintellectual and multipledisabilities. Journal of Applied Research in Intellectual Disabilities, 18, 151-161. https://doi.org/10.1111/j.1468-3148.2005.00244.x 